\title{
First Occurrence of a Juvenile Chain Pickerel (Esox niger) in Ontario Waters of Lake Ontario
}

\author{
Brian P. MORrison ${ }^{1,2,4}$ and DANIEL J. MOORE ${ }^{3}$ \\ ${ }^{1}$ Ganaraska Region Conservation Authority, 2216 County Road 28, Port Hope, Ontario L1A 3V8 Canada \\ ${ }^{2}$ Current address: 2620 Farmcrest Avenue, Peterborough, Ontario K9L 1H7 Canada \\ ${ }^{3}$ Central Lake Ontario Conservation Authority, 100 Whiting Avenue, Oshawa, Ontario L1H 3 T3 Canada \\ ${ }^{4}$ Corresponding author: brianmorrison@trentu.ca
}

Morrison, Brian P., and Daniel J. Moore. 2017. First occurrence of a juvenile Chain Pickerel (Esox niger) in Ontario waters of Lake Ontario. Canadian Field-Naturalist 131(4): 331-334. https://doi.org/10.22621/cfn.v131i4.1946

This paper documents the first juvenile Chain Pickerel (Esox niger) captured in Ontario waters of Lake Ontario. It was found during August 2016 monitoring activities at Port of Newcastle. Its occurrence represents a significant westward range expansion from recently documented adults in the eastern basin of Lake Ontario/Bay of Quinte/St. Lawrence River, likely colonizing from United States waters of Lake Ontario.

Key Words: Esox niger; Chain Pickerel; range expansion; Ontario; Lake Ontario

\section{Introduction}

Chain Pickerel (Esox niger) is a small- to mediumsized (adult total length 381-762 mm), largely piscivorous member of the pike family (Esocidae), which usually inhabits lakes and large rivers with associated submerged aquatic vegetation and water depths of less than $3 \mathrm{~m}$ (Scott and Crossman 1998). Its native range is principally the Atlantic coastal plains, including parts of the St. Lawrence River, the New York (south) shore of Lake Ontario, and portions of Quebec. It is considered naturalized in New Brunswick, Nova Scotia, and other parts of Quebec (Greeley 1939; Coffie 1998; Page and Burr 2011; Carlson et al. 2016), with introductions expanding its range west of this (Coffie 1998).

Chain Pickerel has been widely introduced as a sport fish and has subsequently expanded its range in many parts of the United States and eastern Canada (Coffie 1998). Adult Chain Pickerel, native to the United States waters of Lake Ontario (Holm et al. 2009), were first confirmed in the eastern basin of Lake Ontario between 2008 and 2010 (Hoyle and Lake 2011). Adult Chain Pickerel have continued to be present in the upper St. Lawrence/eastern Lake Ontario basin (J. Hoyle, personal communication), with evidence of natural reproduction on the New York side of the eastern basin of Lake Ontario (Carlson et al. 2016). Hoyle and Lake (2011) speculated that range expansion west of the Bay of Quinte may be more difficult because the shoreline is largely devoid of warm, vegetated waters.

This paper documents the first occurrence of a juvenile Chain Pickerel in Canadian waters of Lake Ontario and a significant range expansion to the north shore of Lake Ontario.

\section{Methods}

Annual monitoring occurs across a series of Lake Ontario coastal wetland habitats as part of the Durham
Region Coastal Wetland Monitoring Program (DRCWMP) and Bay of Quinte Remedial Action Plan. Sixteen wetlands are sampled annually in the Durham region and 15 wetlands are sampled on a 3-year rotation in the Bay of Quinte (Figure 1). The DRCWMP protocol is used at both locations; it notes fisheries, vegetation, and chemical characteristics of each wetland at the time of sampling (Environment Canada and Central Lake Ontario Conservation Authority 2007; Moore 2016).

Fishes are sampled via boat electrofishing along a linear transect, with six sampling points located $8 \mathrm{~m}$ apart, resulting in approximately 4-m-diameter sampling points along the 44-m transect. Each point along the transect is sampled for 20 electrofishing seconds, with one crew member netting all fishes for later processing. Genetic species identification was conducted by barcoding at the $\mathrm{CO} 1$ mitochondrial gene and crossreferencing sequences with the GENBANK database.

\section{Results}

On 22 August 2016, a 153-mm total length, 19-g juvenile Chain Pickerel (Figure 2) was captured by boat electrofishing at Port of Newcastle wetland (435 $53^{\prime} 50$. $0172 " \mathrm{~N}, 78^{\circ} 34^{\prime} 37.7322^{\prime \prime}$ ) during annual monitoring activities. The fish was considered a juvenile based on its size. It was preserved in $95 \%$ ethanol and sent to the Royal Ontario Museum for verification (ROM 101354).

The specimen had 15 branchiostegal rays, fully scaled gill covers, a prominent suborbital bar that does not slope backward, four pores on the ventral side of each mandible, and snout length greater than the distance from back of eye to top of gill slit (Table 1). In addition, DNA was extracted from the Chain Pickerel and it was positively identified using the GENBANK database, i.e., the $\mathrm{CO} 1$ mitochondrial gene (barcode) matched other Chain Pickerel sequences (799 base pairs

A contribution towards the cost of this publication has been provided by the Thomas Manning Memorial Fund of the Ottawa Field-Naturalists' Club. 


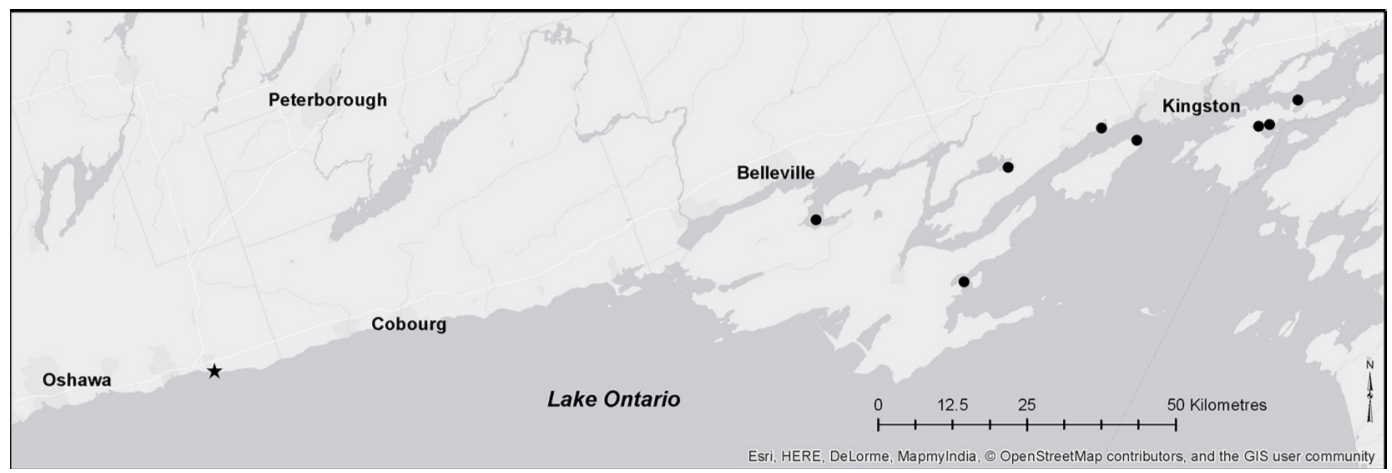

FIgURE 1. Location of juvenile Chain Pickerel (Esox niger) captured at Port of Newcastle (star) and recent adult Chain Pickerel captures in the Bay of Quinte and eastern basin of Lake Ontario (black dots).

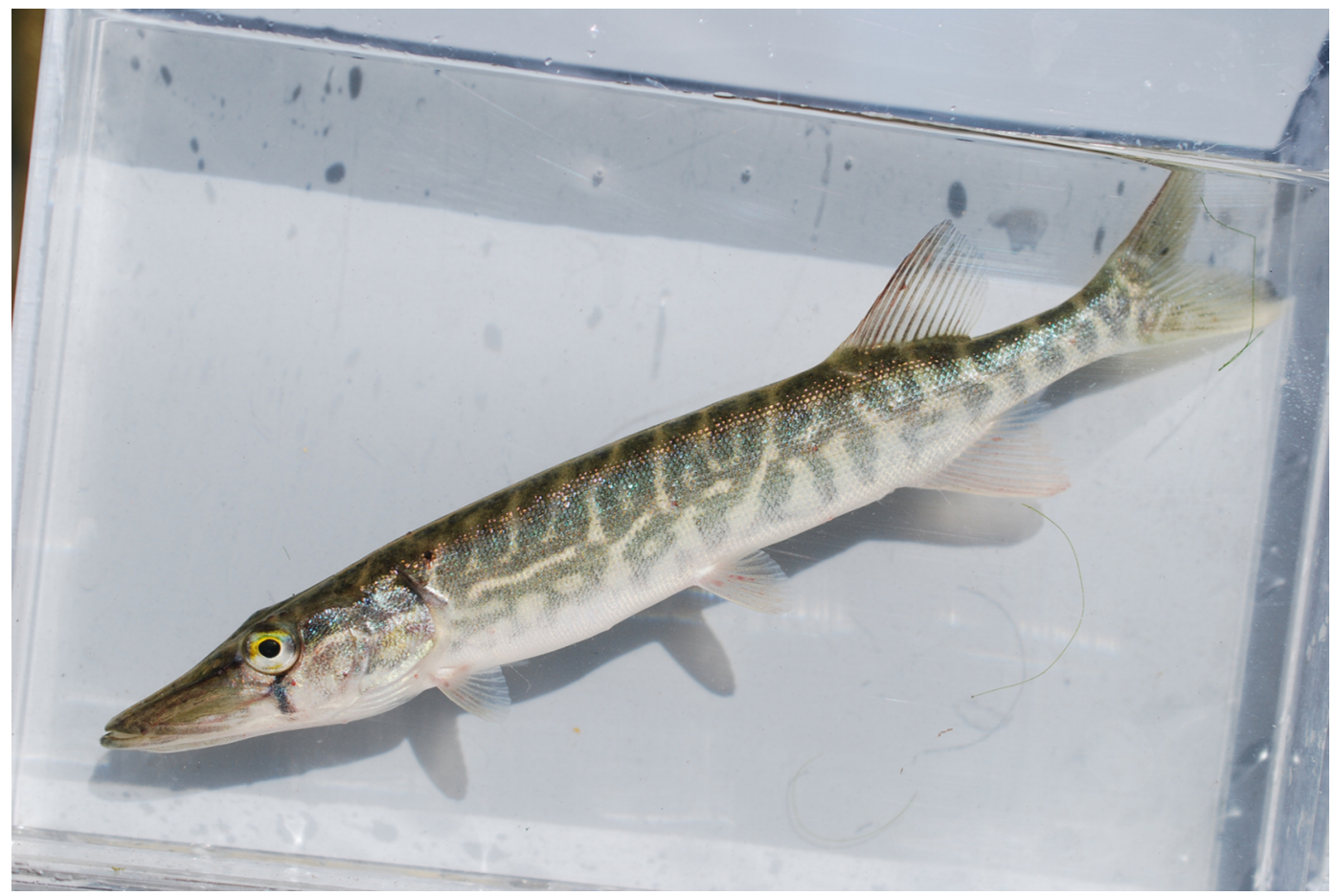

Figure 2. First juvenile Chain Pickerel (Esox niger) caught in Ontario (total length $153 \mathrm{~mm}$ ). Photo: B. Morrison.

of 802 matched; E. Holm and H. Haddrath, personal communications). Subsequent supplemental monitoring on 1 September 2016, using both boat electrofishing and seining, failed to detect any additional specimens.

Other fish species captured on 22 August 2016 in the Port of Newcastle wetland included Common Carp (Cyprinus carpio), Johnny Darter (Etheostoma nigrum), Largemouth Bass (Micropterus salmoides), Pumpkinseed (Lepomis gibbosus), Rock Bass (Ambloplites rupestris), and Round Goby (Neogobius melanostomus).
Turbidity and conductivity in this coastal wetland were 5-15 nephelometric turbidity units (NTU) and 300-500 $\mu \mathrm{S} / \mathrm{cm}$, respectively, based on sampling in 2016 and earlier. Total aquatic plant cover at this location was around 60\% and included Curly-leaved Pondweed (Potamogeton crispus L.), Eurasian Water-milfoil (Myriophyllum spicatum L.), Small Pondweed (Potamogeton pusillus L.), and Leafy Pondweed (Potamogeton foliosus Rafinesque). The substrate was quite coarse, consisting of a mix of contents from old gabion baskets and silt/sand. Aquatic vegetation throughout the marsh was inter- 
TABLE 1. Identification features of Ontario esocids.

\begin{tabular}{|c|c|c|c|c|}
\hline Species & $\begin{array}{c}\text { No. } \\
\text { branchiostegal } \\
\text { rays }\end{array}$ & $\begin{array}{c}\text { Gill } \\
\text { cover }\end{array}$ & $\begin{array}{c}\text { Suborbital } \\
\text { bar }\end{array}$ & $\begin{array}{l}\text { No. lower } \\
\text { jaw pores }\end{array}$ \\
\hline Chain Pickerel (Esox niger) & $14-17$ & Fully scaled & \multirow{4}{*}{ Prominent } & 8 (4 on each side $)$ \\
\hline Grass Pickerel (Esox americanus vermiculatus) & $11-13$ & Fully scaled & & 8 (4 on each side) \\
\hline Northern Pike (Esox lucius) & $14-15$ & Partly scaled & & 10 (5 on each side) \\
\hline Muskellunge (Esox masquinongy) & $16-19$ & Partly scaled & & $12-18(6-9$ on each side $)$ \\
\hline
\end{tabular}

spersed with pockets of well-vegetated areas, but most of the area had little cover. Port of Newcastle is considered a drowned river mouth; a portion has been dredged for a marina.

\section{Discussion}

Chain Pickerel is believed to be native in New York waters of Lake Ontario (Carlson et al. 2016, and references within), but it has recently colonized Ontario waters in the eastern basin and upper St. Lawrence River, with increasing abundance in the former (Hoyle and Lake 2011). The capture of this Chain Pickerel is significant, as it is both the first juvenile captured, and its location was more than $100 \mathrm{~km}$ west of the closest record in Ontario waters.

Chain Pickerel have remained elusive in the Lake Ontario basin despite significant sampling in warm, highly vegetated habitats. Since 2002, 185 wetland sampling events have been completed in the Durham region and 50 in the Bay of Quinte under the DRCWMP. In addition, other agencies, largely the Ontario Ministry of Natural Resources and Forestry, carry out sampling in the Bay of Quinte using numerous gear types, and commercial fisheries expend a large amount of effort in the bay (Ontario Ministry of Natural Resources and Forestry 2016). Although significant wetland sampling occurs in the Durham region, limited sampling is done in adjacent Lake Ontario nearshore waters. The absence of adult records in the Durham region could be attributed to low abundance, a low sampling effort in areas with water depth greater than $2 \mathrm{~m}$, and the timing of DRCWMP sampling, i.e., after adult fish have spawned and left wetland habitats (Environmental Canada and Central Lake Ontario Conservation Authority 2007; Sauvanet et al. 2013). Samarasin et al. (2017) have noted that sampling effort should be greater (either single or replicate sampling) in areas with more species and in larger wetlands to improve chances of detection. In addition to varying effort, challenges differentiating juvenile Chain Pickerel from other Esocidae could be complicating the recognition of range expansion.

Range expansion is difficult to monitor because of the rarity of a species at its leading edge and the potential for misidentification and hybridization with similar species. Although, not certain, it is unlikely that this specimen was introduced (e.g., via bait bucket or aquarium release); thus, this capture is likely evidence that the range of the Chain Pickerel is expanding westward in Ontario and that natural reproduction may have occurred in the Port of Newcastle wetland. It is unclear what role a significant drought in 2016 may have played in forcing fishes out of small coastal wetlands and concentrating them in larger wetland complexes with easy access from Lake Ontario, such as Port of Newcastle. Continued monitoring, with increased emphasis on areas that have been poorly sampled, should help determine abundance and confirm natural reproduction of Chain Pickerel in the Ontario waters of Lake Ontario.

Although the captured specimen appears to be a pure Chain Pickerel, it is possible that hybrids between Chain Pickerel and Northern Pike (Esox lucius) maybe present. Such a hybrid would be difficult to identify, and we recommend that any Esox that is not clearly a Northern Pike or Grass Pickerel be preserved and a tissue sample saved for genetic analysis. Specimens and tissues can be submitted for identification to the Royal Ontario Museum.

Limitations on the Chain Pickerel's range expansion are thought to be related to water temperatures and the amount of suitable habitat. Mandrak (1989) predicted that climate warming might lead to further expansion and establishment of Chain Pickerel in Ontario waters of Lake Ontario or connected waterbodies. Hoyle and Lake (2011) indicated that the lack of warm, heavily vegetated habitats in portions of Lake Ontario could create physical barriers to Chain Pickerel dispersal. Although the north shore of Lake Ontario has limited habitat for Chain Pickerel, the fish appears to have bridged this barrier. It is unknown how such habitat features affect dispersal of Chain Pickerel at various life stages or what mechanisms prompt movement or colonization. It is also not known what impact this species might have on existing fish communities, its potential for hybridization with other Esocidae (e.g., E. lucius), or its effect on recreational and commercial fisheries. Chain Pickerel have been implicated in simplifying fish communities, reducing overall fish abundance, and truncating the size spectrum of fishes in waterbodies where it has been introduced (Mitchell et al. 2010), but these effects may be muted because piscivorous species are already present in the existing fish community. Continued monitoring is encouraged to track the continued presence and establishment of Chain Pickerel in Ontario waters. 


\section{Acknowledgements}

We thank Erling Holm (Royal Ontario Museum) for confirming identification, participating in subsequent sampling, encouraging us to document this occurrence, and reviewing the manuscript. We also thank Oliver Haddrath (Royal Ontario Museum) for genetic analysis; Jim Hoyle and Colin Lake (Lake Ontario Management Unit, Ontario Ministry of Natural Resources and Forestry) for their comments and perspectives on Chain Pickerel status in Lake Ontario; Mike Parna, Anna Miles, and Robin Brand for their assistance in the field; and Dr. Nicholas Mandrak and an anonymous reviewer whose comments and suggestions greatly improved this manuscript.

\section{Literature Cited}

Carlson, D. M., R. A. Daniels, and J. J. Wright. 2016. Atlas of Inland Fishes of New York. Volume 7. New York State Museum, Albany, New York, USA.

Coffie, P. A. 1998. Status of the Chain Pickerel, Esox niger, in Canada. Canadian Field-Naturalist 112: 133-140. Accessed 27 March 2018. https://www.biodiversitylibrary.org/item/ 106776\#page/141/mode/1up.

Environment Canada and Central Lake Ontario Conservation Authority. 2007. Durham Region Coastal Wetland Monitoring Project: Methodology Handbook. Central Lake Ontario Conservation Authority, Oshawa, Ontario, Canada.

Greeley, J. R. 1939. Fishes of the watershed with annotated list. In A Biological Survey of the Lake Ontario Watershed (Including all Waters from Little Sandy Creek Westward Except the Genesee and Oswego River Systems): Supplement to the Twenty-ninth Annual Report, 1939, Volume 16. New York (State) Conservation Department, Albany, New York, USA.

Holm, E., N. Mandrak, and M. Burridge. 2009. The ROM Field Guide to Freshwater Fishes of Ontario. Royal Ontario Museum, Toronto, Ontario, Canada.

Hoyle, J. A., and C. Lake. 2011. First occurrence of Chain Pickerel (Esox niger) in Ontario: possible range expansion from New York waters of eastern Lake Ontario. Canadian Field-Naturalist 125: 16-21. https://doi.org/10.22621/cfn. v125i1.1116

Mandrak, N. E. 1989. Potential invasion of the Great Lakes by fish species associated with climatic warming. Journal of Great Lakes Research 15: 306-316. https://doi.org/10. 1016/S0380-1330(89)71484-2

Mitchell, S. C., J. E. LeBlanc, and A. J. Heggelin. 2010. Impact of introduced Chain Pickerel (Esox niger) on lake fish communities in Nova Scotia, Canada. Nova Scotia Department of Fisheries and Aquaculture, Halifax, Nova Scotia, Canada.

Moore, D. M. 2016. The use of historical data to describe changes in fish communities over time. M.E.Sc. thesis, University of Toronto, Scarborough, Ontario, Canada.

Ontario Ministry of Natural Resources and Forestry. 2016. Lake Ontario fish communities and fisheries: 2015 annual report of the Lake Ontario Management Unit. Ontario Ministry of Natural Resources and Forestry, Picton, Ontario, Canada.

Page, L. M., and B. M. Burr. 2011. A Field Guide to Freshwater Fishes of North America North of Mexico. Houghton Mifflin Harcourt, Boston, Massachusetts, USA.

Samarasin, P., S. M. Reid, and N. E. Mandrak. 2017. Optimal sampling effort required to characterize wetland fish communities. Canadian Journal of Fisheries and Aquatic Sciences 74: 1251-1259. https://doi.org/10.1139/cjfas-2016 $-0424$

Sauvanet, J., G. Bourdier, J. Colombet, A. Viallefont, C. Lemarchand, and C. Desvilettes. 2013. Estimating Esox lucius (Esocidae, Esociformes) density and population structure in a large European alluvial river: the Allier (France). Journal of Ichthyology 53: 617-627. https://doi. org/10.1134/S003294521305010X

Scott, W. B., and E. J. Crossman. 1998. Freshwater Fishes of Canada. Galt House Publications, Oakville, Ontario, Canada.

Received 13 April 2017

Accepted 29 December 2017 